\title{
Murraya paniculata and Swinglea glutinosa as Short-Term Transient Hosts of 'Candidatus Liberibacter asiaticus' and Implications for the Spread of Huanglongbing
}

\author{
Juan Camilo Cifuentes-Arenas, ${ }^{1,2}$ George Andrew Charles Beattie, ${ }^{3}$ Leandro Peña, $, 4,5$ and Silvio Aparecido Lopes ${ }^{1,2, \dagger}$ \\ ${ }^{1}$ School of Agricultural and Veterinarian Sciences, São Paulo State University, Jaboticabal, São Paulo, Brazil \\ ${ }^{2}$ Departamento Científico, Fundecitrus, Araraquara, São Paulo, Brazil \\ ${ }^{3}$ School of Science and Health, Western Sydney University, Penrith, New South Wales, Australia \\ ${ }^{4}$ Laboratório de Biotecnologia Vegetal, Pesquisa and Desenvolvimento, Fundecitrus, Araraquara, São Paulo, Brazil \\ ${ }^{5}$ Instituto de Biología Molecular y Celular de Plantas, Consejo Superior de Investigaciones Científicas, Universidad Politécnica de Valencia, \\ Valencia, España \\ Accepted for publication 16 August 2019.
}

ABSTRACT

\begin{abstract}
Murraya paniculata and Swinglea glutinosa are aurantioid hosts of the Asian citrus psyllid (ACP) Diaphorina citri, the principal vector of 'Candidatus Liberibacter asiaticus' (Las). Las is the pathogen associated with huanglongbing (HLB), the Asian form of which is the most devastating disease of Citrus species and cultivars (Rutaceae: Aurantioideae). M. paniculata is a common ornamental and S. glutinosa is grown as an ornamental, a citrus rootstock, and a hedgerow fence plant. Because of the uncertain status of these plants as reservoirs of Las, a series of cross-inoculation bioassays were carried out in different environments, using infected Valencia sweet orange (Citrus $\times$ aurantium) infected shoot tops as a source of inoculum and $D$. citri nymphs and adults reared on $M$. paniculata and $S$. glutinosa to inoculate pathogen-free Valencia orange plantlets. In contrast to sweet orange, Las was more unevenly distributed and reached much lower titers in $M$. paniculata and $S$. glutinosa. Infections in M. paniculata and S. glutinosa were also transient. Very few
\end{abstract}

insects that successfully acquired Las from M. paniculata and S. glutinosa were able to transmit the pathogen to healthy citrus. Transmission rates were low from $M$. paniculata (1.0\%) and S. glutinosa (2.0\%) and occurred only in a controlled environment highly favorable to Las and ACP using 10-day-old adults that completed their life cycle on Laspositive plants. Our study showed that in HLB-endemic areas, $M$. paniculata and S. glutinosa can be deemed as epidemiologically dead-end hosts for Las and are not important alternative hosts of the pathogen for transmission to citrus. However, under a combination of conditions highly favorable to Las infection and transmission and in the absence of effective quarantine procedures, these plants could eventually serve as carriers of Las to regions currently free from HLB.

Keywords: bacteriology, disease control and pest management, ecology and epidemiology, etiology
Murraya paniculata (L.) Jack (syn. M. exotica L.: Mabberley 2016) and Swinglea glutinosa (Blanco) Merr. are rutaceous species in the tribe Aurantieae (Citreae) in the orange subfamily Aurantioideae. M. paniculata, commonly known as orange jasmine, is native to southern China and northern Vietnam. It is now a widely grown ornamental plant in subtropical and tropical regions of the world, including Brazil. S. glutinosa is native to Luzon in the northern region of the Philippine Archipelago. It is occasionally grown as an ornamental and as a rootstock for citrus. As a rootstock, $S$. glutinosa is used to reduce tree size, increase tolerance to drought, and confer resistance to gummosis, a disease caused by Phytophthora oomycetes, and Citrus tristeza virus, a disease spread by aphids (del Valle et al. 2004; Restrepo et al. 1987; Rondón et al. 1993; Venning 1957). S. glutinosa is also used as a hedgerow fence plant in Colombia, where farmers have become increasingly concerned that it and $M$. paniculata may enhance the

†Corresponding author: S. A. Lopes; silvio.lopes@fundecitrus.com.br

Funding: Financial support was provided by the Fundo de Defesa da Citricultura (Fundecitrus/Brazil) and Coordenação de Aperfeiçoamento de Pessoal de Nível Superior (CAPES). J. C. Cifuentes-Arenas received a CAPES scholarship.

*The $\boldsymbol{e}$-Xtra logo stands for "electronic extra" and indicates that nine supplementary figures are published online.

The author(s) declare no conflict of interest.

C 2019 The American Phytopathological Society spread of 'Candidatus Liberibacter asiaticus' (Las), reported for the first time in Colombia in 2015 (Instituto Colombiano Agropecuario 2015).

Las is a Gram-negative, unculturable $\alpha$-proteobacterium associated with the most destructive, widely distributed, and incurable disease of citrus, known as huanglongbing (HLB) (Bové 2006) or citrus greening. The bacterium colonizes citrus phloem leading to bearing of insipid fruit, severe leaf and fruit drop, and thus reduced productivity and premature death of infected trees (Bassanezi 2018; Jagoueix et al. 1994). The bacterium is most commonly and widely transmitted by the psyllid Diaphorina citri Kuwayama (Hemiptera: Sternorrhyncha: Liviidae) (Bové 2006), a phloem feeding insect that proliferates in the presence of soft young new shoots (Cifuentes-Arenas et al. 2018) and environmental conditions that favor its reproduction (Aubert 1988; Husain and Nath 1927). Bacterium acquisition and transmission efficiency of the psyllid varies with environmental conditions, feeding duration, life cycle stage, and plant tissue type (Ammar et al. 2016; Pelz-Stelinski et al. 2010; Sétamou et al. 2016; Wu et al. 2018) and with pathogen population in new shoots (Lopes et al. 2013, 2017). Involvement of $M$. paniculata and S. glutinosa could enhance the spread of Las in two ways: (i) as hosts of $D$. citri, contributing to the incidence of the psyllid near citrus orchards; or (ii) if also susceptible to Las, as reservoirs of the vector and the pathogen in and near citrus orchards.

The importance of these plants as hosts of $D$. citri is well known for $M$. paniculata, on which a single female at $25^{\circ} \mathrm{C}$ may lay up to 626 eggs during its lifespan, with most of the eggs becoming adults (Alves et al. 2014; Liu and Tsai 2000; Nava et al. 2007). Volatiles 
emitted by new shoots of $M$. paniculata attract the psyllid (Patt and Sétamou 2010) and influence the dispersal of the psyllid in the field (Tomaseto et al. 2016). The information available on S. glutinosa as a potential reservoir of $D$. citri is less well known. Adult feeding was initially reported by Tirtawidjaja (1981). From 2006 to 2008, it was the second most favored host of the psyllid after $M$. paniculata (cited as M. paniculata var. exotica) in field comparisons of more than 20 Citrus species and Citrus relatives in Indonesia (Subandiyah et al. 2008). Eggs, nymphs, and adults were detected on hedgerow trees in Colombia (Ángel et al. 2014; Ebratt-Ravelo et al. 2011; King 2012).

The importance of M. paniculata and S. glutinosa as reservoirs of Las is not clear. In Indonesia, Tirtawidjaja (1981) reported that 10 months after insect feeding inoculation, 58 of 200 and 5 of 100 2-week-old seedlings of $M$. paniculata and $S$. glutinosa, respectively, exhibited symptoms of citrus vein phloem degeneration (the then common name for HLB in Indonesia). The study by Tirtawidjaja (1981) preceded the use of molecular techniques. Using quantitative PCR (qPCR), Lopes et al. (2010) detected Las in Brazil in several M. paniculata trees (cited as M. exotica) growing in cities. Bacterial titers were, however, 4 logs lower (average 3.0 log cells $\mathrm{g}^{-1}$ of tissue) than those found in citrus in backyards. Unlike in citrus trees, Las infections in $M$. paniculata seemed to be transient. Low frequencies and/or low titers of Las in M. paniculata and/or D. citri psyllids found feeding on $M$. paniculata also were reported in Thailand (Jantasorn et al. 2012; Koizumi et al. 1996), Guangdong and Fuzhou in China (Deng et al. 2007; Li and Ke 2002), and in Florida (Manjunath et al. 2008; Ramadugu et al. 2016; Walter et al. 2012) and Texas in the United States (Kunta et al. 2011, 2014). In addition, Las was not detected in the roots of $M$. paniculata during a field survey carried out from 2011 to 2012 in Texas (de la Garza 2013). Under controlled conditions, the results of transmission experiments involving $M$. paniculata are variable. Using grafting, Lopes et al. (2010) failed to transmit Las from citrus to $M$. paniculata and vice versa. However, using insects that had previously fed on infected citrus, reported transmission rates varied, with $0 \%$ in Thailand (Koizumi et al. 1996), 17\% in Indonesia (Tirtawidjaja 1981), and $11 \%$ in Brazil (Beloti et al. 2018). Damsteegt et al. (2010) also reported transmission of Las by D. citri adults to M. paniculata (34 of 36 plants referred to as $M$. paniculata, and 21 of 23 plants referred to as $M$. exotica) and tested backinoculations, based on 40 adult psyllids per plant, that led to transmission of the pathogen from 10 infected M. paniculata plants to 2 of 10 sweet orange plants.

The rapid spread of Las in citrus orchards, the wide distribution of M. paniculata and S. glutinosa in many citrus regions of South/ Central America and Asia, and the lack of more comprehensive information on these species as hosts of Las stimulated us to assess their suitability to Las colonization and their potential as sources of Las for $D$. citri-mediated transmission to citrus groves.

\section{MATERIALS AND METHODS}

Plants and growth conditions. Three experiments were carried out in a controlled environmental room (CER), a greenhouse, and a growth chamber (GC), involving 6-month-old "mini" or 3-year-old plants of Valencia sweet orange (Citrus $\times$ aurantium L.), all grafted onto Rangpur lime (C. limonia Osbeck; also known as Cravo lemon in Brazil), and 2-year-old seedlings of $M$. paniculata and $S$. glutinosa. The mini plants were grown in 300-ml conical plastic tubes and the remaining plants were grown in 1.7- or 4.7liter pots containing a sterilized mixed substrate composed of $80 \%$ Pinus sp. bark, $15 \%$ vermiculite, and 5\% charcoal (Multiplant Citrus; Terra do Paraíso, Holambra, SP, Brazil). All plants were regularly irrigated with water and fortnightly irrigated with a solution of minerals as previously described (Cifuentes-Arenas et al. 2018). Inside the CER, plants and insects were exposed to average daily temperature from 24 to $27^{\circ} \mathrm{C}, 55$ to $78 \% \mathrm{RH}$, and a 12-h/12-h light/dark photoperiod with 200 to $300 \mu \mathrm{mol} \mathrm{m}^{-2} \mathrm{~s}^{-1}$ of photosynthetically active radiation (PAR). Inside the greenhouse, they were exposed to temperatures that varied from 17.5 to $32.2^{\circ} \mathrm{C}$ and 53.0 to $92.0 \% \mathrm{RH}$. Inside the GC, they were exposed to a daily temperature regime of $3 \mathrm{~h}$ at $27^{\circ} \mathrm{C}$, followed by $6 \mathrm{~h}$ at $34^{\circ} \mathrm{C}$ and $3 \mathrm{~h}$ at $27^{\circ} \mathrm{C}$ with light $\left(300 \mu \mathrm{mol} \mathrm{m}{ }^{-2} \mathrm{~s}^{-1}\right.$ of PAR $)$, and $12 \mathrm{~h}$ at $24^{\circ} \mathrm{C}$ with darkness, with average $65 \% \mathrm{RH}$.

Las transmission by shoot grafting or insect feeding. Two experiments were concomitantly carried out in which Las transmission was attempted with the use of adult psyllids and shoot top grafting. For the psyllid-inoculation experiment, the insects were reared on 2-year-old Las-infected plants of Valencia sweet orange grafted onto Swingle citrumelo (Citrus $\times$ insitorum Mabb., formerly $\times$ Citroncirus webberi J. Ingram \& H. Moore) and maintained inside the CER. Sets of five to seven 15- to 20-day-old adult insects were transferred and confined inside a mesh sleeve cage onto single new shoots of 44,39, and 42 plants of $S$. glutinosa, Valencia, and $M$. paniculata, respectively. New shoot emission was induced 3 weeks beforehand by pruning each plant 10 to $15 \mathrm{~cm}$ below the branch top. The Valencia new shoots were at phenological stage V3 as defined by Cifuentes-Arenas et al. (2018), and the $S$. glutinosa and $M$. paniculata new shoots had one partially unfurled and one or more tender expanding leaflets (Fig. 1). After an inoculation access period (IAP) of 7 days, the insects were removed and stored at $-20^{\circ} \mathrm{C}$, and the plants were sprayed with insecticide (Abamectin Nortox EC; $18.0 \mathrm{~g}$ per liter of active ingredient Abamectin and $1 \mathrm{ml}$ of product per liter of water) to kill any psyllid eggs or nymphs present. The plants remained inside the CER during the IAP and for an additional 15-day period. After these periods, the plants were transferred to the greenhouse.

For the shoot top inoculation experiment, shoot segments $7.5 \pm$ $1.5 \mathrm{~cm}$ long were removed from the same group of Las-infected Valencia plants used to produce infective psyllids and were grafted at the top of a single branch of 92 healthy seedlings of $M$. paniculata and to 40 and 39 healthy plants of $S$. glutinosa and Valencia. The Las-positive shoots were fixed onto the healthy seedlings or plants with Parafilm strips. They contained five to seven symptomatic and fully expanded mature leaves and were similar in diameter $(\sim 4.5$ to $6 \mathrm{~mm}$ ) to the receptor branch. All shoots were confirmed to be infected by Las through qPCR (see below). As controls, groups of 20 plants per each species were top grafted in the same way with shoot segments removed from healthy Valencia. Inoculated and control plants remained inside the greenhouse. The grafting procedure was considered successful if the grafted shoot remained green, with or without leaves, for at least 4 months after inoculation (MAI). The plants with dead grafts were discarded. To assess the potential of the experimental plants to recover from infection, 1 year after inoculation, the grafted shoots were removed from all plants, with the cut made at $3 \mathrm{~cm}$ below the graft union, and their leaves were processed for qPCR (Supplementary Fig. S1).

Progress of Las infection and colonization. To determine rates of Las infection and infection progress, the plants were
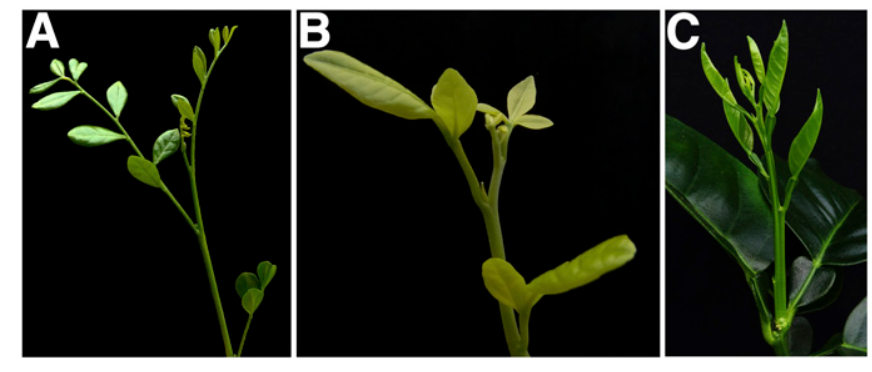

Fig. 1. Typical appearance of developing shoots of A, orange jasmine (Murraya paniculata), B, Swinglea glutinosa, and C, Valencia sweet orange (Citrus $\times$ aurantium) used for the insect feeding inoculation experiments. 
sampled every 4 to 5 months, from the inoculation date up to the 32 nd month. The samples were composed of (i) symptomatic or asymptomatic leaves that were present at the top of the top-grafted or insect-inoculated plants or (ii) leaves present at the base of the stem and branches that grew just below the graft union of the topgrafted plants. The samples were processed (Teixeira et al. 2005) and analyzed by qPCR (Li et al. 2006) as described below. To determine the extent of plant colonization by Las, 2 weeks after the 4 MAI sampling date (after qPCR results were obtained), samples consisting of four to six mature leaves, partial strips of stem bark, and four to six subsamples of fibrous roots randomly chosen all over the root volume were taken from a few selected plants-namely, five of each species that had been inoculated by top grafting, nine of M. paniculata and S. glutinosa, and 10 of Valencia that had been inoculated by insects. The top-grafted plants had threshold cycle (Ct) values $<34.0$, and those inoculated by insects had $\mathrm{Ct}$ values less than or greater than 34.0.

Influence of the environment on Las colonization. The extent of plant colonization and the influence of the environment on the ability of Las to move to and colonize new shoots was further assessed using a new set of Las-positive and symptomatic plants, which included $12 \mathrm{M}$. paniculata, eight $\mathrm{S}$. glutinosa, and 10 Valencia plants. The plants had been individually exposed for 15 days to groups of 30 to 40 adult Las-positive psyllids reared on Las-positive Valencia. For this study, the psyllid-exposed plants were maintained inside the CER, in which the temperature averaged $25^{\circ} \mathrm{C}$, a condition highly favorable to Las acquisition by $D$. citri (Wu et al. 2018) or Las multiplication in plant tissues (S. Lopes, unpublished data). Five months after inoculation, a combined sample of four to six mature leaves and a single randomly chosen immature shoot (prepruning shoots) were removed from each plant for qPCR (Supplementary Fig. S2A). One plant of each species was also thoroughly sampled by removing additional new shoots, mature leaves, and 4-mm-wide by 3-cm-long bark strips from the lower and upper half portions of the stem in M. paniculata and $S$. glutinosa, and one from the rootstock and three from the scion stem in Valencia plants. The plants were then pruned and defoliated. Half of the plants remained at $25^{\circ} \mathrm{C}$ inside the CER, and the other half were transferred to the $\mathrm{GC}$ where the temperature varied between 24 and $34^{\circ} \mathrm{C}$, as described above. The plants were maintained in these environments until the new shoots that emitted after pruning reached 3 to $4 \mathrm{~cm}$ in length, which occurred after 20 to 25 days inside the CER and 15 to 22 days inside the GC. The postpruning shoots (one to three per plant) were collected and processed for qPCR.

Las acquisition by $D$. citri and back-inoculations. Two experiments were carried out inside the CER. In the first experiment (Las acquisition by adults), $11 \mathrm{M}$. paniculata, nine $S$. glutinosa, and eight Valencia Las-positive plants with Las titers above the equivalent of $2.2 \mathrm{log}$ Las cells $\mathrm{g}^{-1}$ of tissue $(\mathrm{Ct} \leq 34.0)$ were selected from previous experiments just after the third date of leaf sampling (1 year after inoculation). The plants were lightly pruned and defoliated to induce new shoots as described. Twenty days later, thirty-five 10-day-old Las-negative adult $D$. citri were confined inside a single mesh sleeve cage onto each of the total 28 plants. Previous qPCR analysis of random samplings equivalent to $\sim 5 \%$ of the total insects to be used in the experiment confirmed the absence of Las. The insects remained confined on the plants for 1-, 2-, 3-, or 6-day acquisition access periods (AAPs). At the end of the first three AAPs, groups of three to five insects were removed from each plant and stored at $-20^{\circ} \mathrm{C}$ for qPCR. At the end of the 6-day AAP, the remaining insects were transferred and confined onto 24 Valencia plants using three to eight insects per shoot, one shoot per plant, and eight plants per source of inoculum (M. paniculata, S. glutinosa, or Valencia). After an IAP of 8 days, the insects were removed and stored at $-20^{\circ} \mathrm{C}$ for $\mathrm{qPCR}$, and the insect-exposed plants were transferred to the greenhouse. The plants were observed routinely for symptom expression and were sampled 1 year later for qPCR analysis (Supplementary Fig. S3).
In a second experiment (Las acquisition by adults and nymphs), new groups of 10 Las-positive $M$. paniculata, S. glutinosa, or Valencia plants were maintained inside the CER for additional 5 months after an IAP of 15 days to improve the expression of leaf symptoms. Then, sets of 10 to 15 Las-negative adult psyllids were confined on each plant for 15 AAPs. The insects were allowed to feed on young immature leaves, new shoots, and symptomatic and asymptomatic mature leaves and to lay eggs on new shoots. At the end of the AAP, the adults were removed and stored at $-20^{\circ} \mathrm{C}$, and the laid eggs were allowed to develop to a first generation of adults (F1). When most F1 adults were 10 days old, they were transferred individually to Valencia mini plants containing one single shoot at stage V2 or V3, as defined by Cifuentes-Arenas et al. (2018). A total of 208, 50, and 30 mini plants received adults from Las-positive M. paniculata, S. glutinosa, or Valencia plants, respectively. After an IAP of 8 days, the insects were removed and stored at $-20^{\circ} \mathrm{C}$ for qPCR. The inoculated plants remained inside the CER for an additional 60-day period and were then transferred to the greenhouse. The plants were observed routinely for symptom expression and were sampled at $10 \mathrm{MAI}$ for qPCR (Supplementary Fig. S4).

DNA extraction and qPCR analysis. Total genomic DNA was extracted from $0.3 \mathrm{~g}$ of plant tissues (leaf midrib or leaflet rachis, bark or fibrous roots) or from individual or sets of adult psyllids. Plants and psyllids were macerated using the TissueLyser II system (Qiagen, Valencia, CA). DNA was extracted using the cetyltrimethyl ammonium bromide protocol of Murray and Thompson (1980) as described by Teixeira et al. (2005). qPCRs were run in a total volume of $12 \mu \mathrm{l}$ containing the master mix, $1 \mu \mathrm{l}$ of total DNA (100 $\mathrm{ng} / \mu \mathrm{l})$ from plant tissues or $3 \mu \mathrm{l}$ of nonquantified DNA from insects, and $150 \mathrm{nM}$ each of the primers HLBaspr targeting Las sequences ( $\mathrm{Li}$ et al. 2006) and the internal control primers for the wingless genes for samples of D. citri (Manjunath et al. 2008; Thao et al. 2000) or the cytochrome oxidase for samples of plant tissues (Li et al. 2009). qPCR was performed in a StepOne Plus thermocycler (Applied Biosystems) using the reaction protocol of $\mathrm{Li}$ et al. (2006). Quantification $\mathrm{Ct}$ values were automatically adjusted using StepOne software. Ct values $>34.0$ or undetermined were considered negative for the presence of Las (Lopes et al. 2013), and those $<34.0$ were further converted into $\log _{10}$ values of bacterium cells per gram of tissue or individual insects, as described (Lopes et al. 2013).

Data analysis. At $4 \mathrm{MAI}$, the frequencies of Las infection between plant species, and between tissues within each species, were compared through the $\chi^{2}$ test or Fisher exact test (when expected frequencies were lower than 5). Bacterium titer data were submitted to analysis of variance of two factors, with inoculation method (top grafting and insect feeding) as factor A and plant species (M. paniculata, S. glutinosa, and Valencia) as factor B, followed by mean separation through the Tukey test $(P<0.05)$.

\section{RESULTS}

Progress of Las infection and colonization of $M$. paniculata, S. glutinosa, and Valencia plants. All sets of psyllids used in the inoculation experiment contained Las, with average titers varying from $3.78 \pm 0.62$ to $6.76 \pm 0.12 \mathrm{log}$ Las cells per psyllid, and most individuals were alive at the end of the IAP. Similarly, all Valencia shoot tops used as inoculum were mottled and contained Las, with $6.71 \pm 0.15 \log$ cells $\mathrm{g}^{-1}$ of leaf midribs (minimum 3.00 and maximum 7.38; $\mathrm{Ct}$ values: average $18.94 \pm 0.50$, minimum 16.70, and maximum 31.33). However, several shoots progressively died after grafting. Shoot survival rates were $77.2 \%$ in $M$. paniculata, $52.5 \%$ in $S$. glutinosa, and $53.8 \%$ in Valencia at 4 MAI. From the total shoot grafts that were alive at 4 MAI, 20.0, 56.3, and $76.9 \%$ survived until 12 MAI in M. paniculata, S. glutinosa, and Valencia, respectively. On the shoots that survived, some leaves abscised, with those that remained attached to the shoots continuing to 
express mottling symptoms (Supplementary Fig. S5). At 12 MAI, all top graft shoots were removed in attempts to assess plant recovery from infection. At this evaluation date, Las titers in the shoot tips varied from 4.68 to 6.08 cells $\mathrm{g}^{-1}$. In contrast to the infected shoots used as inoculum, most shoots from healthy Valencia remained alive and flushed on the three plant species (data not shown). On $M$. paniculata, however, the new shoots were smaller and did not flush again, likely owing to some level of physiological incompatibility. The survival rates of the entire plants also varied. Excluding the plants that were destructively sampled at 4 MAI (see below), survival rates of M. paniculata, S. glutinosa, and Valencia plants progressively declined to $62.1,93.8$, and $56.3 \%$ in those inoculated by grafting and to $42.4,77.1$, and $51.7 \%$ in those inoculated by insects.

At 4 MAI, Las was detected in $63.4,66.7$, and $61.1 \%$ of the 71 M. paniculata, $21 \mathrm{~S}$. glutinosa, and 21 Valencia plants, respectively, that had been top grafted with Las-positive shoot tips and in 9.5, 20.5 , and $87.2 \%$ of the $42 \mathrm{M}$. paniculata, 44 S. glutinosa, and 39 Valencia plants, respectively, exposed to Las-positive psyllids (Table 1). Two weeks later, 14 plants of each M. paniculata and $S$. glutinosa and 15 plants of Valencia were selected for destructive sampling to determine the extent of plant colonization by Las, with the remaining plants maintained in the greenhouse for further evaluations. Leaves, stem, and roots were sampled from the selected plants, totaling 42 samples of $M$. paniculata and $S$. glutinosa each and 45 of Valencia. The frequency of Las-positive samples was dependent on the species $\left(\chi^{2}=16.79\right.$, degrees of freedom $[d f]=2$; $P=0.0002$ ). Las colonized Valencia (32 of 45 samples) more extensively than M. paniculata (14 of 42) and S. glutinosa (16 of 42) (Table 2). Within each species, the frequency of Las-positive samples was significantly dependent on the type of sampled tissue for $S$. glutinosa $\left(\chi^{2}=9.89, d f=2 ; P=0.0071\right)$ but not for M. paniculata $\left(\chi^{2}=2.79, d f=2 ; P=0.2484\right)$ or Valencia $\left(\chi^{2}=2.73\right.$, $d f=2 ; P=0.2557)$. Las was most frequently found in leaves in $M$. paniculata and Valencia and in stem tissues in S. glutinosa (Table 2). In S. glutinosa, Las was found in the roots of one plant. For Las titers, no differences were found between inoculation methods but there were differences between species (method: $F_{1,117}=0.55 ; P=0,46$; species: $F_{2,117}=104.97 ; P<0.01$; interaction of method $\times$ species: $\left.F_{2,117}=0.84 ; P=0.43\right)$, with higher titers in Valencia (4.35 to 5.41) than in M. paniculata (2.46 to 3.19 ) or S. glutinosa (2.72 to 3.44) (Table 2). However, the different tissues within each species contained similar titers. Las titers were lower in leaves of M. paniculata (average $-49.2 \%$ ) and S. glutinosa (average $-38.9 \%$ ) than in Valencia (average $5.47 \mathrm{log}$ Las cells) throughout all of the assessment dates in both groups of inoculated plants (Table 1). Unlike the Las-positive Valencia plants, which always showed symptoms along the experiment, the availability of symptomatic mature leaves for sampling decreased over time in M. paniculata and S. glutinosa (see below).

In the group of plants that were graft inoculated, the proportion of infected M. paniculata and $S$. glutinosa progressively declined over

TABLE 1. Frequencies of 'Candidatus Liberibacter asiaticus'-positive plants and titers in leaves of Murraya paniculata, Swinglea glutinosa, and Valencia sweet orange at different sampling intervals

\begin{tabular}{|c|c|c|c|c|c|c|}
\hline \multirow[b]{2}{*}{$\mathrm{MAI}^{\mathrm{a}}$} & \multicolumn{2}{|c|}{ M. paniculata } & \multicolumn{2}{|c|}{ S. glutinosa } & \multicolumn{2}{|c|}{ Valencia } \\
\hline & PCR positive/total (n) & $\log \pm \mathrm{SE}$ & PCR positive/total $(n)$ & $\log \pm \mathrm{SE}$ & PCR positive/total $(n)$ & $\log \pm \mathrm{SE}$ \\
\hline \multicolumn{7}{|c|}{ Top-grafting inoculation } \\
\hline 4 & $45 / 71$ & $2.80 \pm 0.06$ & $14 / 21$ & $3.63 \pm 0.09$ & $13 / 21$ & $5.12 \pm 0.42$ \\
\hline $12^{\mathrm{b}}$ & $16 / 65$ & $2.77 \pm 0.10$ & $9 / 16$ & $3.71 \pm 0.11$ & $10 / 13$ & $6.32 \pm 0.46$ \\
\hline 17 & $9 / 55$ & $2.62 \pm 0.10$ & $7 / 15$ & $3.33 \pm 0.19$ & $12 / 13$ & $5.06 \pm 0.50$ \\
\hline 22 & $2 / 46$ & $2.77 \pm 0.06$ & $2 / 15$ & $2.40 \pm 0.14$ & $8 / 10$ & $5.03 \pm 0.37$ \\
\hline 4 & $4 / 42$ & $2.76 \pm 0.26$ & $9 / 44$ & $3.58 \pm 0.22$ & $33 / 39$ & $5.57 \pm 0.27$ \\
\hline 8 & $0 / 33$ & - & $5 / 34$ & $2.72 \pm 0.15$ & $24 / 29$ & $6.24 \pm 0.05$ \\
\hline 12 & $1 / 32$ & 2.89 & $5 / 34$ & $3.13 \pm 0.26$ & $23 / 28$ & $6.03 \pm 0.09$ \\
\hline 17 & $3 / 30$ & $2.80 \pm 0.16$ & $3 / 33$ & $3.04 \pm 0.21$ & $21 / 25$ & $5.78 \pm 0.13$ \\
\hline 22 & $0 / 16$ & - & $1 / 31$ & 2.88 & $12 / 16$ & $5.18 \pm 0.17$ \\
\hline 27 & $0 / 14$ & - & $0 / 28$ & - & $12 / 16$ & $5.31 \pm 0.18$ \\
\hline
\end{tabular}

a MAI $=$ months after inoculation

b Date of inoculum source removal (graft).

${ }^{c}$ Dashes indicate no detection of the pathogen.

TABLE 2. Frequencies and titers of 'Candidatus Liberibacter asiaticus' in samples of leaves, stem barks, and fibrous roots of top-grafted and adult psyllid inoculated plants of Murraya paniculata, Swinglea glutinosa, and Valencia sweet orange 15 days after 4 MAI sampling

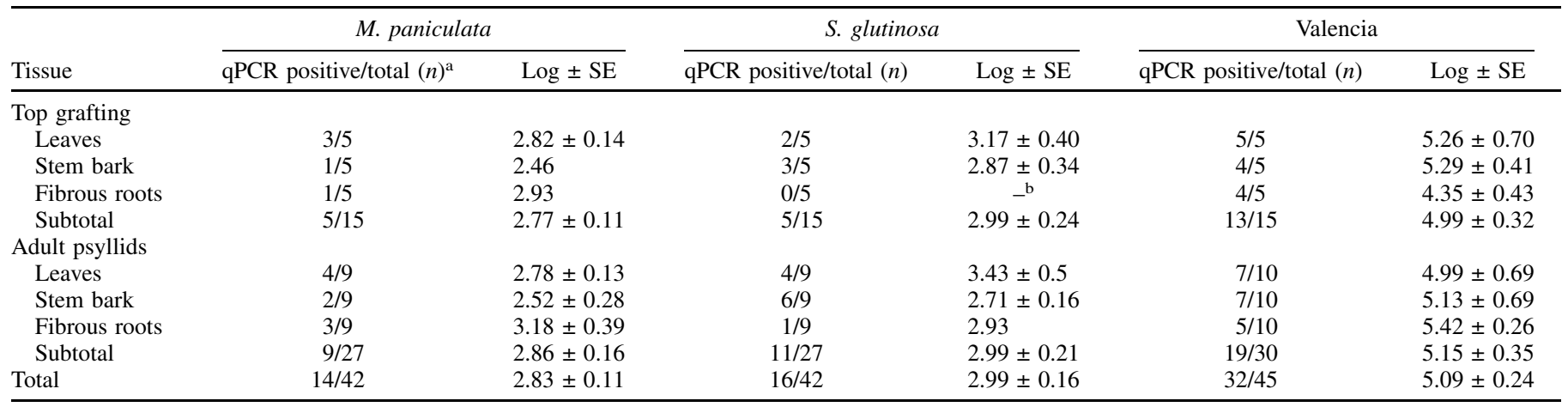

${ }^{a}$ qPCR = quantitative PCR.

$\mathrm{b}$ Dashes indicate no detection of the pathogen. 
time, with the rate of decline greatly increasing following the removal of the shoots used as the source of inoculum (Table 1). In $M$. paniculata plants, the incidence of infected plants decreased from $63.4 \%$ at $4 \mathrm{MAI}$ to $24.16 \%$ at $12 \mathrm{MAI}$ and to $0.0 \%$ at $27 \mathrm{MAI}$. At 8 MAI, Las was detected in 5 of 26 plants (average $2.86 \pm 0.25$ $\log$ cells) that had tested negative at 4 MAI, but these plants resulted negative for Las in subsequent evaluations. One plant reappeared as Las-positive at 32 MAI (2.5\%) (Table 1). Similarly, in S. glutinosa, the rate of Las infection declined from $66.7 \%$ at $4 \mathrm{MAI}$ to $56.3 \%$ at $12 \mathrm{MAI}$ and to $13.3 \%$ at $22 \mathrm{MAI}$. None of these plants were positive for Las at 27 or 32 MAI. Unlike M. paniculata and S. glutinosa plants, the rate of infected Valencia plants increased over time (Table 1). All Valencia plants but one that were positive for Las at 4 MAI remained infected until the last evaluation date (32 MAI). In addition, two of three Valencia plants that were free of Las at 4 MAI were Las positive in the following assessment date $(8 \mathrm{MAI})$ and remained infected until the end of the experiment.

In the group of plants exposed to Las-positive psyllids, the proportion of infected $M$. paniculata plants declined from $9.5 \%$ at 4 MAI to $0.0 \%$ at $8 \mathrm{MAI}$, but one appeared infected again at $12 \mathrm{MAI}$ and continued as Las negative in further evaluations. Three additional $M$. paniculata plants were found infected at 17 MAI, but all were free from Las from the 22 to 32 MAI evaluations (Table 1). Similarly, the proportion of infected S. glutinosa plants declined from $20.5 \%$ at 4 MAI to $0.0 \%$ at 27 and 32 MAI. Two plants negative for Las at 4 MAI tested positive at 8 MAI and remained as such until the $12 \mathrm{MAI}$ evaluation. On the following evaluation dates, these plants were free from infection. At 17 MAI, Las was detected in two additional formerly Las-negative plants, which were negative for Las in further evaluations (Table 1). In Valencia, all infected plants at 4 MAI contained Las on all of the following evaluation dates and, as observed for the graft-inoculated group, the rate of Las infection remained $>70 \%$ from 8 to 32 MAI.

Symptom development and progression over time were also evaluated in both graft- and insect-inoculated plants. Symptoms developed in all Las-positive Valencia, but only on some of the Las-positive M. paniculata or S. glutinosa plants. On Valencia, the symptoms appeared first on mature leaves of the flushes that appeared after inoculation. Symptoms were present in $14 \%$ of all Las-positive Valencia at 4 MAI but progressed in successive evaluations to affect $100 \%$ of infected plants, regardless of the method of inoculation used. They were characterized by typical HLB mottling associated or not with mineral deficiencies or corky veins and were as described by Lopes et al. (2009a) and Folimonova et al. (2009) (Supplementary Fig. S6). For M. paniculata plants, an asymmetric light chlorosis associated or not with mineral deficiencies was found on the leaflets of at least one single mature leaf of half of the Las-positive plants. In two of the M. paniculata plants, the rachis of some leaves or the midrib of some of the leaflets also exhibited corky segments (Fig. 2; Supplementary Fig. S7). On $S$. glutinosa, the mottling patterns were like those in Valencia (Fig. 3; Supplementary Fig. S8) and were found in one-third of the infected plants. None of the symptomatic leaves of $S$. glutinosa developed corky veins. In contrast to Valencia, on both $M$. paniculata and $S$. glutinosa, the symptoms were more evident in the leaflets closest to the inoculation grafting sites and decreased in incidence over time as a result of the successive samplings and the nonemergence of new symptomatic leaves. On plants exposed to Las-positive insects, the symptoms were lighter and, as in those inoculated by grafts, they also decreased in severity over time. In addition, all M. paniculata and S. glutinosa plants that were positive for Las and exhibited symptoms at 4 MAI completely recovered healthy attributes at the end of the experiment, lacking any Las symptoms.

Influence of the environment on plant colonization by Las. The environment affects colonization of new shoots by Las (Lopes et al. 2013, 2017). To test whether this phenomenon would occur in M. paniculata or S. glutinosa, half of a new group of
Las-positive and symptomatic plants that had been maintained at $25^{\circ} \mathrm{C}$ (a condition favorable to Las) were transferred to a 24 to $34^{\circ} \mathrm{C}$ environment. Before transfer, the plants had been sampled for qPCR, pruned, and defoliated.

Before pruning, Las was present in all pooled symptomatic leaf or leaflet samples and in 8 of 12 shoots of M. paniculata, 3 of 8 in S. glutinosa, and in all 10 shoots of Valencia (Table 3). One plant of each species was extensively sampled. The frequency of Las infection in these plants varied. In M. paniculata, Las was present in 2 of 6 new shoots (average 2.63 log cells $\mathrm{g}^{-1}$ of tissue) and in 6 of 11 mature symptomatic or asymptomatic leaves (average $2.55 \mathrm{log}$ ), but not in any of the two partial bark strips removed from the upper and lower half of the main stem (Fig. 2). In S. glutinosa, Las was present in three of seven new shoots (average $3.83 \mathrm{log}$ ), in four of nine mature leaflets (average $3.18 \mathrm{log}$ ), and in the upper stem bark sample with $2.78 \log _{\text {cells g }}{ }^{-1}$ tissue (Fig. 3). In Valencia, Las was present in all 21 sampled sites, including bark tissues of the main stem (average $5.33 \mathrm{log}$ ), symptomatic and asymptomatic leaves (average $6.24 \mathrm{log}$ ), and new shoots (average $6.07 \mathrm{log}$ ) (Supplementary Fig. S9).

Pruning and defoliation led to emission of new shoots on all plants in both environments. The development of new shoots was slower (20 to 25 days) in the cooler environment of the CER ( 24 to $24^{\circ} \mathrm{C}$ ) than inside the warmer and variable environment ( 15 to 22 days) of the $\mathrm{GC}$ ( 24 to $34^{\circ} \mathrm{C}$ ). Inside the CER, Las was detected in one shoot each of $M$. paniculata and $S$. glutinosa plants, which contained 2.43 and $3.42 \mathrm{log}$ cells $\mathrm{g}^{-1}$ of tissue respectively, and in five of five shoots of Valencia, with an average $4.79 \log$ (Table 3 ). Inside the GC, Las was not detected in M. paniculata or S. glutinosa but was present in all Valencia shoots, with an average titer $10.4 \%$ lower than that in CER plants (Table 3).

Las transmission experiments. Transmission experiments were carried out to determine how M. paniculata and S. glutinosa plants compared with Valencia as sources of inoculum to backinfect Valencia sweet orange plants. Plants from both inoculated groups were used. The average Las titers were $2.64 \pm 0.13,3.73 \pm$ 0.15 , and $6.12 \pm 0.43 \log$ cells $\mathrm{g}^{-1}$ of tissue in mature leaves of the graft-inoculated $M$. paniculata, $S$. glutinosa, and Valencia plants, respectively, and $2.85 \pm 0.08,3.35 \pm 0.18$, and $5.63 \pm 0.43 \log$ for the insect-inoculated M. paniculata, $S$. glutinosa, and Valencia plants, respectively (Table 4).

We further tested Las acquisition from Las-positive M. paniculata, $S$. glutinosa, and Valencia and inoculation to Valencia using adult D. citri. Las-negative insects were allowed to feed on infected plants for 1-, 2-, 3-, or 6-day AAPs. After the first three AAPs, an insect sample was taken and frozen for qPCR. The insects of the 6-day AAP were also frozen for qPCR, but after their confinement for 7-day IAPs on healthy Valencia plants. None of the 199 insects that fed on infected M. paniculata, regardless of AAP, acquired Las (Table 4). In addition, none of the eight Valencia plants that had been exposed to the 6-day AAP insects on $M$. paniculata became infected. Of those that fed on infected $S$. glutinosa, 1 to 4 of the 135 insects acquired Las (2.2 to $8.9 \%$ ) during the first three AAPs as did 6 of 23 insects after the 6-day AAP. Two of the eight Valencia plants exposed to the 6-day AAP insects became infected by Las. Of the insects that had fed on infected Valencia, 15 to 18 individuals of 40 acquired Las (37.5 to $45 \%$ ) during the 1- to 3-day AAPs and 48 of 62 acquired Las (77.4\%) during the 6-day AAP. However, four of the eight insect-exposed Valencia plants became infected (Table 4).

In the second attempt, we tested Las acquisition from Laspositive M. paniculata, S. glutinosa, and Valencia using adults and nymphs of $D$. citri and inoculation to Valencia using the first generation of adults. At the end of a 15-day AAP, 1 of $56(1.8 \%), 12$ of $45(26.7 \%)$, and 44 of $50(88.0 \%)$ of the original psyllid populations that fed on M. paniculata, S. glutinosa, and Valencia, respectively, acquired Las (Table 4). At the end of AAP, all remaining adults were removed, and the plants were left inside the CER to allow development of nymphs and adults from the laid eggs. 
When most adults were 10 days old, a random selection of 208, 50, and 30 individuals from the M. paniculata, S. glutinosa, and Valencia plants were individually transferred and confined for a 7day IAP onto healthy Valencia plantlets. At the end of IAP, the insects were tested by qPCR. A total of $14.4,34.0$, and $100 \%$ of the psyllids that developed on Las-positive M. paniculata, S. glutinosa, and Valencia contained Las, with respective average titers of 2.78, 2.76, and $5.96 \log$ Las cells per psyllid body. However, only 0.96 and $2.0 \%$ of the plantlets exposed to the insects reared on infected
M. paniculata or $S$. glutinosa plants, respectively, became infected, in contrast to $83.33 \%$ of those exposed to the insects reared onto infected Valencia (Table 4).

\section{DISCUSSION}

Our interest in $M$. paniculata as a potential reservoir for liberibacters that infect citrus began in 2004, when Las and 'Candidatus Liberibacter americanus' (Lam) were detected for the

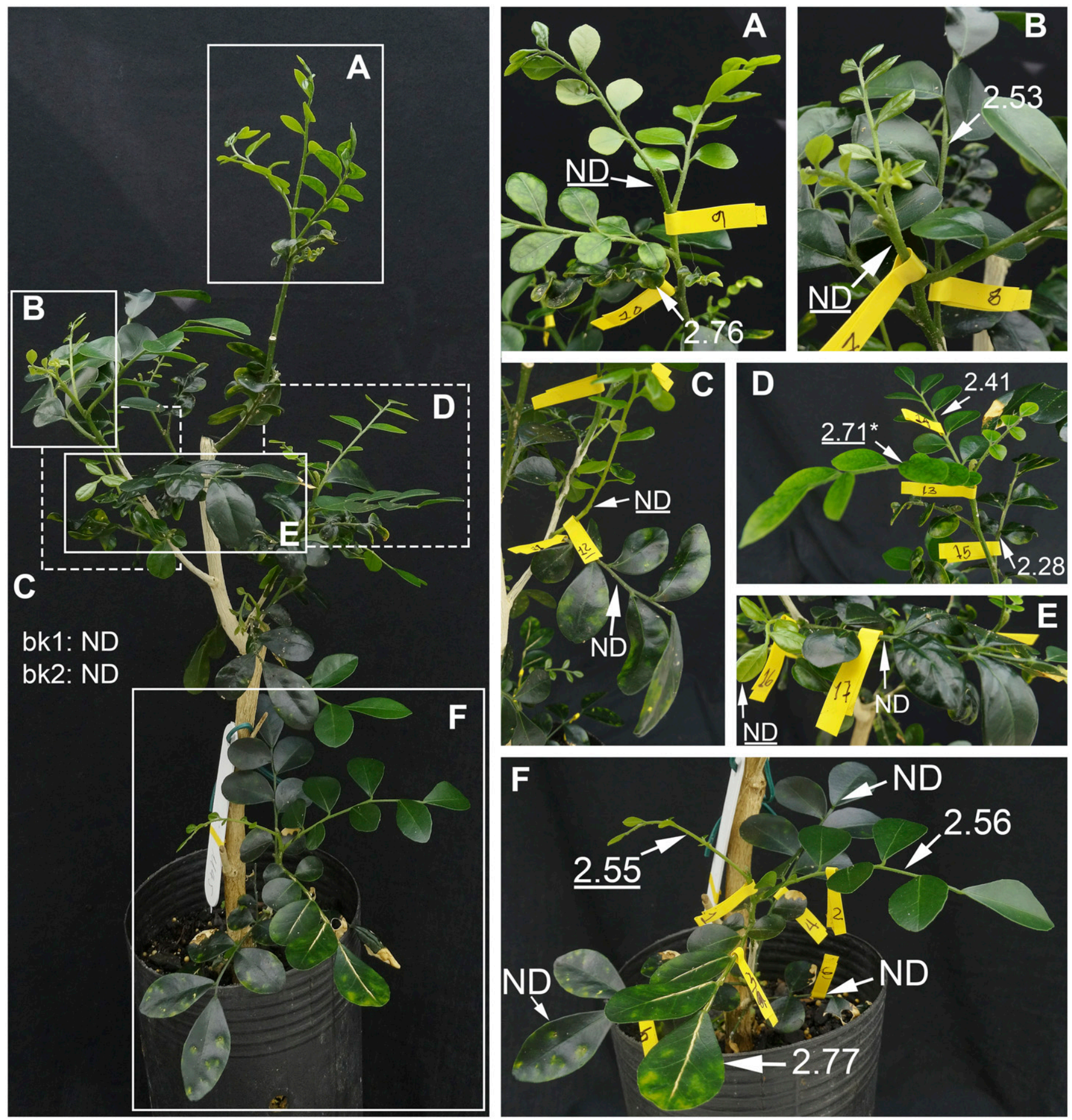

Fig. 2. Murraya paniculata plant infected by 'Candidatus Liberibacter asiaticus' (Las) indicating the distinct sampling sites for quantitative PCR analysis and the estimated respective bacterium titers (in $\log _{10}$ cells per gram of tissue) on symptomatic or asymptomatic leaves, new shoots (underlined values), and partial strips of stem bark taken for the upper (bk1) or lower (bk2) half of the plant. Images in panels $\mathbf{A}$ to $\mathbf{F}$ on the right of the figure represent detailed views of the different sampled sites, highlighted by the white rectangles in the whole plant photo on the left side of the figure (relative plane of observation: solid rectangles are front views; dashed rectangles are back views). ND = Las was not detected. 

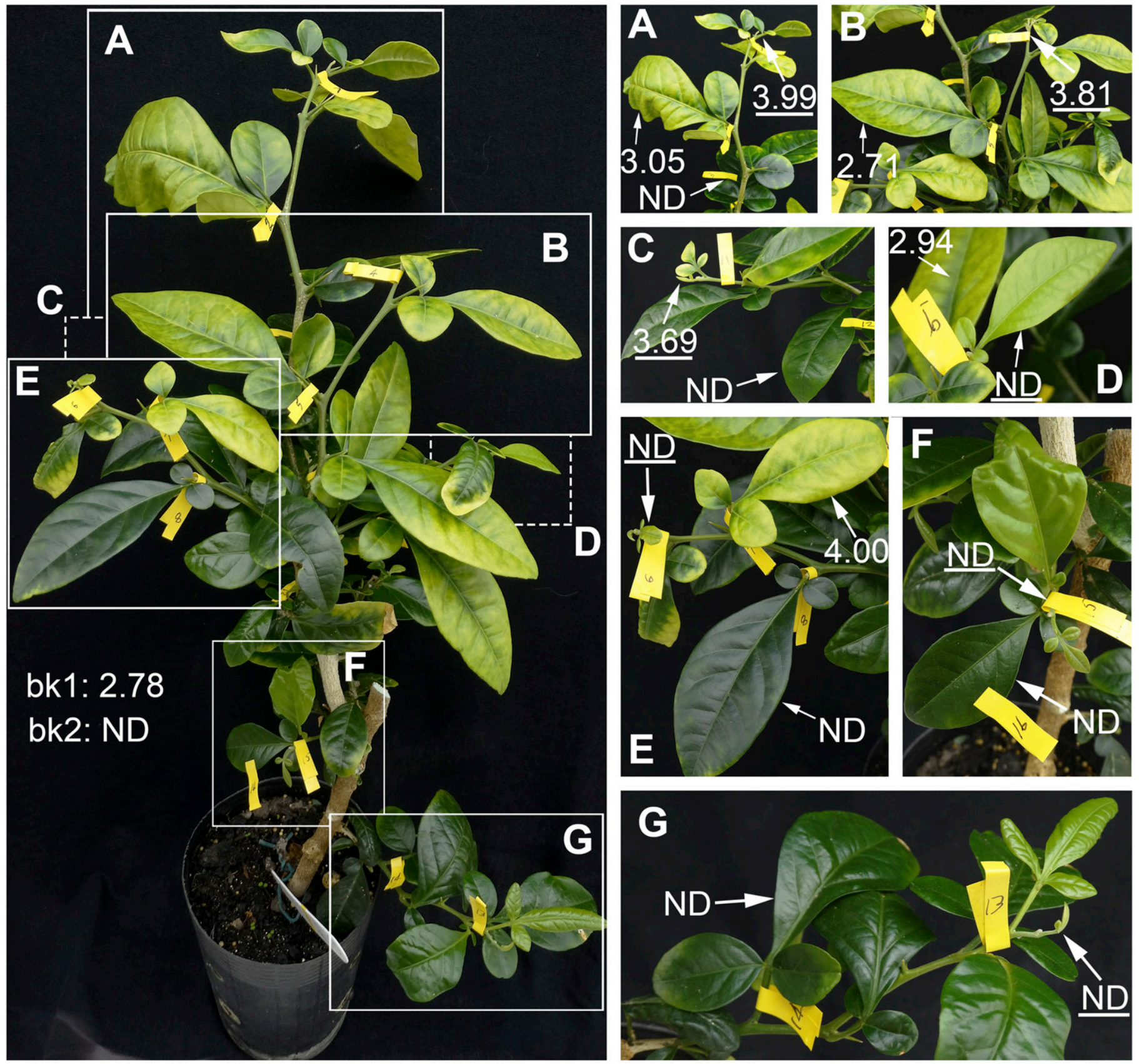

Fig. 3. Swinglea glutinosa plant infected by 'Candidatus Liberibacter asiaticus' (Las) indicating the distinct sampling sites for quantitative PCR analysis and the estimated respective bacterium titers (in $\log _{10}$ cells per gram of tissue) on symptomatic or asymptomatic leaves, new shoots (underlined values), and partial strips of stem bark taken for the upper (bk1) or lower (bk2) half of the plant. Images in panels A to G on the right of the figure represent detailed views of the different sampled sites, highlighted by the white rectangles in the whole plant photo on the left side of the figure (relative plane of observation: solid rectangles are front views; dashed rectangles are back views). ND = Las was not detected.

TABLE 3. Influence of the environment on frequencies and titers of 'Candidatus Liberibacter asiaticus' (Las) in symptomatic mature leaves and new shoots of Murraya paniculata, Swinglea glutinosa, and Valencia sweet orange plants

\begin{tabular}{|c|c|c|c|c|c|c|}
\hline \multirow[b]{2}{*}{ Time and tissue for sampling } & \multicolumn{2}{|c|}{ M. paniculata } & \multicolumn{2}{|c|}{ S. glutinosa } & \multicolumn{2}{|c|}{ Valencia } \\
\hline & PCR positive/total $(n)$ & $\log \pm \mathrm{SE}^{\mathrm{a}}$ & PCR positive/total $(n)$ & $\log \pm \mathrm{SE}$ & PCR positive/total $(n)$ & $\log \pm \mathrm{SE}$ \\
\hline \multicolumn{7}{|l|}{ Prepruning } \\
\hline Symptomatic mature leaf & $12 / 12$ & $2.64 \pm 0.10$ & $8 / 8$ & $3.31 \pm 0.15$ & $10 / 10$ & $6.00 \pm 0.04$ \\
\hline \multicolumn{7}{|l|}{ Postpruning ${ }^{\mathrm{c}}$} \\
\hline New shoot (AR) & $1 / 6$ & 2.43 & $1 / 4$ & 3.42 & $5 / 5$ & $4.79 \pm 0.22$ \\
\hline New shoot (GC) & $0 / 6$ & - & $0 / 4$ & - & $5 / 5$ & $4.29 \pm 0.39$ \\
\hline
\end{tabular}

${ }^{a} \log _{10}$ of Las genomes per gram of tissue $(y=-0.2998 x+11.042)$ or psyllid $(y=-0.2904 x+11.085)$ (Lopes et al. 2013). Dashes indicate no detection of the pathogen.

b New shoots emitted naturally and that were present at the moment of the pruning within the acclimatized room.

${ }^{c} \mathrm{AR}=$ acclimatized room $\left(25^{\circ} \mathrm{C} \pm 2.70 \% \pm 10 \mathrm{RH}\right.$, and a 12-h photoperiod with photosynthetically active radiation $\left.=300 \mu \mathrm{mol} \mathrm{m} \mathrm{m}^{-2} \mathrm{~s}^{-1}\right)$ and $\mathrm{GC}=$ growth chamber ( 24 to $34^{\circ} \mathrm{C} \pm 2.70 \% \pm 10 \mathrm{RH}$, and a 12-h photoperiod with photosynthetically active radiation $\left.=300 \mu \mathrm{mol} \mathrm{m}^{-2} \mathrm{~s}^{-1}\right)$. 
first time in M. paniculata trees growing in farms and urban areas in the central region of São Paulo State in Brazil (Lopes et al. 2005, 2006). Subsequent field surveys determined the distribution of infected trees in several cities and suggested that the pathogens differed in their ability to colonize $M$. paniculata, with Las reaching lower titers than Lam (Lopes et al. 2010). With time, Lam incidence declined in citrus groves and also in $M$. paniculata in the cities. However, the opposite happened with Las, which is currently estimated to be present in $\sim 19 \%$ of all citrus trees in the main citrus belt of Brazil (Fundecitrus 2019). Interest in the role of S. glutinosa plants in HLB epidemics started in 2012 in Colombia, where field surveys revealed high populations of $D$. citri in several regions of the country, including commercial citrus areas and nearby places where $S$. glutinosa plants is widely present (mainly hedgerow fences; Cifuentes-Arenas, unpublished results). The interest increased in 2015 when Las was detected in the northern regions of Colombia (Instituto Colombiano Agropecuario 2015). Therefore, elucidating the significance of M. paniculata and S. glutinosa as potential sources of Las to citrus would be important for efficient control of HLB.

Despite research efforts to determine the relevance of $M$. paniculata as a source of Las for transmission by D. citri to citrus, its importance was still unclear or controversial. The relevance of $S$. glutinosa was even less clear, as fewer studies have been undertaken with this plant. Most Las transmission studies involving $M$. paniculata have focused on it as the receptor of Las from citrus, with no attempts of backinoculations (Beloti et al. 2018; Tirtawidjaja 1981; Walter et al. 2012). In addition, information has been based mostly on field surveys (Deng et al. 2007; Jantasorn et al. 2012; Kunta et al. 2011, 2014; Manjunath et al. 2008; Ramadugu et al. 2016), use of artificial graft procedures for inoculation (Dai et al. 2005; Hung et al. 2000; Lopes et al. 2010; Miyakawa 1980), studies that had not included citrus as a susceptible host for comparison (Damsteegt et al. 2010), or studies that used an epidemiologically unrealistic qPCR Ct limit criterion to detect Las (Beloti et al. 2018). In Brazil, we were previously unable to transmit Las from sweet oranges to $M$. paniculata using adult $D$. citri, after several attempts involving hundreds of $M$. paniculata plants (S. Lopes, unpublished data). However, in Indonesia, Tirtawidjaja (1981) reported the presence of HLB-like leaf symptoms in $M$. paniculata (and S. glutinosa) seedlings 10 months after exposure of the plants to insects fed on symptomatic citrus. In Brazil, Beloti et al. (2018) reported 30\% transmission rates from citrus to M. paniculata. The results of Tirtawidjaja (1981) were not confirmed by Koizumi et al. (1996), and the results of Beloti et al. (2018) varied between experiments. The only published work involving successful transmission of Las from infected $M$. paniculata plants to pathogenfree citrus plants was that of Damsteegt et al. (2010). Using sets of 40 initially Las-negative adult d psyllids previously fed for 15 days on Las-positive $M$. paniculata and an IAP of 15 days, Damsteegt et al. (2010) found that 2 of 10 sweet orange plants became infected.

In attempts to better understand the importance of $M$. paniculata and $S$. glutinosa as a source of Las to citrus, we undertook a comprehensive research study involving a total of $\sim 650$ M. paniculata, $S$. glutinosa, and Valencia plants as well as two methods of inoculation (top grafting and psyllids) and two environments (one highly and another less favorable to Las infection). We confirmed that Las can be transmitted by $D$. citri from citrus (Valencia) to M. paniculata and S. glutinosa, but at rates much lower than to citrus. In citrus, the transmission rates were similar to those reported by Inoue et al. (2009) and Lopes et al. (2009a), but they were higher than those obtained by Ammar et al. (2018) using adult psyllids reared on Las-positive Rough lemon plants. In our study, the transmission efficiency of Las from citrus to $M$. paniculata and S. glutinosa was higher with the use of infected shoots as inoculum than with the use of adult psyllids, but the persistence of the pathogen in plant tissues followed similar patterns and was temporary in both inoculation methods. The rate of infection declined over time, which confirmed the results of the study by Damsteegt et al. (2010) for two sets of M. paniculata plants (one set referred to as $M$. paniculata, and the other as the synonym, M. exotica) but not the results of Beloti et al. (2018). Moreover, contrary to citrus, Las was detected in M. paniculata and $S$. glutinosa mainly in the tissues close to the shoots used as inoculum, with their removal at $12 \mathrm{MAI}$ causing a rapid decline in levels of infection and recovery of healthy plant aspects.

The lower titers of Las we recorded in $M$. paniculata and $S$. glutinosa than in citrus explain the lower rates of bacterium acquisition and transmission from these plants to citrus. The acquisition rates were higher by nymphs than by adults, confirming previous works carried out with citrus (Ammar et al. 2016; Inoue et al. 2009; Pelz-Stelinski et al. 2010). In an environment highly favorable to Las transmission, very few insects that acquired Las successfully from $M$. paniculata and S. glutinosa were able to transmit the bacterium to healthy citrus plants. The percentage of transmission of Las from $M$. paniculata to citrus was much lower than that obtained by Damsteegt et al. (2010). The discrepancy could be related to the number of insects and plants used for

TABLE 4. Frequencies and titers of 'Candidatus Liberibacter asiaticus' (Las) on Diaphorina citri adults following different acquisition access periods (AAPs) on Las-positive plants of Murraya paniculata, Swinglea glutinosa, and Valencia sweet orange, and frequencies and titers Las on Valencia plants that received D. citri adults in back-inoculation bioassays in experiments 1 and 2 (see the Materials and Methods for details)

\begin{tabular}{|c|c|c|c|c|c|c|}
\hline & \multicolumn{2}{|c|}{ M. paniculata } & \multicolumn{2}{|c|}{ S. glutinosa } & \multicolumn{2}{|c|}{ Valencia } \\
\hline & PCR positive/total $(n)$ & $\log \pm \mathrm{SE}$ & PCR positive/total $(n)$ & $\log \pm \mathrm{SE}$ & PCR positive/total $(n)$ & $\log \pm \mathrm{SE}$ \\
\hline \multicolumn{7}{|l|}{ Experiment 1} \\
\hline Plants $(n)^{\mathrm{a}}$ & 11 & $2.64 \pm 0.13$ & 9 & $3.73 \pm 0.15$ & 8 & $6.12 \pm 0.43$ \\
\hline 1 & $0 / 55$ & - & $2 / 45$ & $2.02 \pm 0.13$ & $15 / 40$ & $1.89 \pm 0.07$ \\
\hline 2 & $0 / 55$ & - & $1 / 45$ & 1.51 & $18 / 40$ & $2.37 \pm 0.12$ \\
\hline 3 & $0 / 55$ & - & $4 / 45$ & $1.85 \pm 0.22$ & $17 / 40$ & $2.32 \pm 0.10$ \\
\hline Plants $(n)$ & 10 & $2.85 \pm 0.08$ & 10 & $3.35 \pm 0.19$ & 10 & $5.63 \pm 0.43$ \\
\hline \multicolumn{7}{|l|}{ AAP (days) } \\
\hline 15 & $1 / 56$ & 2.06 & $12 / 45$ & $2.80 \pm 0.24$ & $44 / 50$ & $3.09 \pm 0.11$ \\
\hline Nymph to adult +10 days & $30 / 208$ & $2.78 \pm 0.21$ & $17 / 50$ & $2.76 \pm 0.20$ & $30 / 30$ & $5.96 \pm 0.04$ \\
\hline Back-inoculations & $2 / 208$ & $5.39 \pm 0.11$ & $1 / 50$ & 2.43 & $25 / 30$ & $5.26 \pm 0.20$ \\
\hline
\end{tabular}

a Number of plants used and average $\log _{10}$ of Las cells per gram of tissue \pm S.E. (log).

$\mathrm{b}$ Healthy 10-day-old psyllids feeding on Las-positive plants during AAPs of 1,2, 3, 6, or 15 days. Dashes indicate no detection of the pathogen.

c Back-inoculations were made with the remaining sets of psyllids after the AAP of 6 days in experiment 1 or with the same 10-day-old psyllids reared on Laspositive plants of experiment 2 after an AAP of 27 days, with an inoculation access period of 7 days. Frequencies and Las titers correspond to the Valencia/ Rangpur plants that received those psyllids, evaluated 10 months after inoculation.

d Estimated AAP: nymph to adult complete cycle plus 10 days postemergence of adults ( $\sim 27$ to 30 days). 
transmission (single in this study versus sets of 40 individuals per plant in their study) and the inoculation exposure time (7- versus 15day IAP), a dose effect previously demonstrated by Raiol-Junior et al. (2017) using detached leaves.

The environment also seemed to negatively affect colonization of new shoots of M. paniculata and S. glutinosa by Las. Contrary to the plants that were maintained in the CER at 24 to $27^{\circ} \mathrm{C}$, none of the shoots that developed on $M$. paniculata and S. glutinosa plants maintained at 24 to $34^{\circ} \mathrm{C}$ (a more realistic field situation) contained Las and the titer of the pathogen in citrus was reduced, thus confirming previous studies (Lopes et al. 2009b, 2013, 2017). Some Las-positive M. paniculata and S. glutinosa and all infected citrus exhibited leaf mottling, which were fully characterized in M. paniculata and S. glutinosa for the first time. However, Las multiplication, and its distribution in these plants, was limited and uneven compared with citrus. The titers in M. paniculata and citrus were in the range found by others (Lopes et al. 2010; Ramadugu et al. 2016). Despite not having been determined in this study, the limitation for the initial establishment of infection, the poor extent of plant colonization, and the subsequent decline in Las incidence in M. paniculata and S. glutinosa may be attributable to physicalchemical characteristics of the phloem of these plants, which may differ from those of citrus (Killiny 2016; Sétamou et al. 2017).

In our study, undertaken in an environment highly favorable to Las and to pathogen acquisition and inoculation by $D$. citri, transmission of Las from infected M. paniculata or S. glutinosa to citrus was very limited. In the field, where trees live in more variable and unfavorable environments, even lower probabilities of transmission would be expected from these species. The transiency of Las infections in $M$. paniculata, first observed in field studies (Lopes et al. 2010) and confirmed here, has now been demonstrated for $S$. glutinosa as well. This finding, plus the fact that the incidence of Las in the offspring of an initially Las-positive colony of $D$. citri rapidly declines over time when reared multiple times on M. paniculata plants (Ammar et al. 2019), indicates that $M$. paniculata and $S$. glutinosa are of negligible importance as reservoirs of Las in HLB-endemic regions, and that both may be deemed as an epidemiologically dead-end hosts for the bacterium, a phenomenon already observed in other pathosystems (Alma et al. 2000; Davidson et al. 2005; Garbelotto et al. 2017; Morilla et al. 2005). These results validate the use of $M$. paniculata as a trap crop for $D$. citri in a push-and-pull strategy to control HLB in HLBendemic areas (Yan et al. 2015) or in a pull-and-kill approach, as it has been already demonstrated to strongly reduce the population of D. citri adults and Las-infected plants in citrus orchards in São Paulo State (Tomaseto et al. 2019). However, M. paniculata and $S$. glutinosa served as source of inoculum to citrus, although at very low rates and under conditions highly favorable to Las infection. Thus, in the absence of effective quarantine procedures, recently infected $M$. paniculata and $S$. glutinosa plants could serve as carriers of Las to regions currently free from HLB.

\section{ACKNOWLEDGMENTS}

We thank F. A. Q. Benedito for important technical help in sample collection and processing.

\section{LITERATURE CITED}

Alma, A., Marzachi, C., D'Aquilio, M., and Bosco, D. 2000. Cyclamen (Cyclamen persicum L.): A dead-end host species for $16 \mathrm{Sr}-\mathrm{IB}$ and -IC subgroup phytoplasmas. Ann. Appl. Biol. 136:173-178.

Alves, G. R., Diniz, A., and Parra, J. 2014. Biology of the huanglongbing vector Diaphorina citri (Hemiptera: Liviidae) on different host plants. J. Econ. Entomol. 107:691-696.

Ammar, E.-D., Hall, D. G., Hosseinzadeh, S., and Heck, M. 2018. The quest for a non-vector psyllid: Natural variation in acquisition and transmission of the huanglongbing pathogen 'Candidatus Liberibacter asiaticus' by Asian citrus psyllid isofemale lines. PLoS One 13:e0195804.
Ammar, E.-D., Ramos, J. E., Hall, D. G., Dawson, W. O., and Shatters, R. G. 2016. Acquisition, replication and inoculation of Candidatus Liberibacter asiaticus following various acquisition periods on Huanglongbing-infected citrus by nymphs and adults of the Asian citrus psyllid. PLoS One 11: e0159594.

Ammar, E.-D., Ramsey, J. S., Mahney, J., Hall, D. G., and Cilia, M. 2019. Effect of host switch between Murraya and citrus plants on acquisition and transmission of huanglongbing (citrus greening) bacterium by the Asian citrus psyllid Diaphorina citri. Page 98 in: Sixth International Research Conference on HLB, Riverside. Journal of Citrus Pathology 6(1). https:// escholarship.org/uc/item/1zp421bn

Ángel, J. E., Hernández, E. G., Herrera, N. A., Gómez, L. Y., Castro, Á. P., Sepúlveda, A. M., et al. 2014. Citrus huanglongbing: Validation of realtime PCR (qPCR) for the detection of Candidatus Liberibacter asiaticus and Candidatus Liberibacter americanus in Colombia. Agron. Colomb. 32:377-389. https://revistas.unal.edu.co/index.php/agrocol/article/view/ 44069

Aubert, B. 1988. Management of the citrus greening disease in Asian orchards. Pages 51-53 in: Proceedings of the Second Asian/Pacific Regional Workshop on Citrus Greening, Lipa, Philippines. B. Aubert, C. Ke, and C. Gonzales, eds. United Nations Development Program, Rome, Italy.

Bassanezi, R. B. 2018. Progress of huanglongbing severity and damage in sweet orange orchards and its implications for the disease management. Citrus Am. 1:31-44.

Beloti, V. H., Alves, G. R., Coletta-Filho, H. D., and Yamamoto, P. T. 2018. The Asian citrus psyllid host Murraya koenigii is immune to citrus huanglongbing pathogen 'Candidatus Liberibacter asiaticus'. Phytopathology 108:1089-1094.

Bové, J. M. 2006. Huanglongbing: A destructive, newly-emerging, century-old disease of citrus. J. Plant Pathol. 88:7-37.

Cifuentes-Arenas, J. C., de Goes, A., de Miranda, M. P., Beattie, G. A. C., and Lopes, S. A. 2018. Citrus flush shoot ontogeny modulates biotic potential of Diaphorina citri. PLoS One 13:e0190563.

Dai, K., Ikeshiro, T., Matsuura, T., Kimura, S., Hamagami, A., Fujiwara, Y., et al. 2005. Investigation of host range of Candidatus Liberibacter asiaticum: Is Murraya paniculata a host plant of Candidatus L. asiaticum? Res. Bull. Plant Prot. Serv. 41:53-57.

Damsteegt, V. D., Postnikova, E. N., Stone, A. L., Kuhlmann, M., Wilson, C., Sechler, A., et al. 2010. Murraya paniculata and related species as potential hosts and inoculum reservoirs of 'Candidatus Liberibacter asiaticus', causal agent of huanglongbing. Plant Dis. 94:528-533.

Davidson, J. M., Wickland, A. C., Patterson, H. A., Falk, K. R., and Rizzo, D. M. 2005. Transmission of Phytophthora ramorum in mixed-evergreen forest in California. Phytopathology 95:587-596.

de la Garza, C. 2013. Testing for Candidatus Liberibacter asiaticus in leaf and root tissue of citrus and orange jasmine. MSc. Thesis. Texas A\&M University.

del Valle, N., Rodríguez, R., and Rodríguez, K. 2004. Comportamiento del tangelo Orlando injertado sobre patrones tolerantes a la tristeza de los cítricos. Cent. Agríc. 31:38-42.

Deng, X., Zhou, G., Li, H., Chen, J., and Civerolo, E. L. 2007. Nested-PCR detection and sequence confirmation of 'Candidatus Liberibacter asiaticus' from Murraya paniculata in Guangdong, China. Plant Dis. 91: 1051.

Ebratt-Ravelo, E. E., Rubio-González, L. T., Costa, V. A., Castro-Ávila, Á. P., Zambrano-Gómez, E. M., and Ángel-Díaz, J. E. 2011. Diaphorina citri (Kuwayama, 1907) and Tamarixia radiata (Waterson, 1922) in citrus crops of Cundinamarca, Colombia. Agron. Colomb. 29:487-493.

Folimonova, S. Y., Robertson, C. J., Garnsey, S. M., Gowda, S., and Dawson, W. O. 2009. Examination of the responses of different genotypes of citrus to huanglongbing (citrus greening) under different conditions. Phytopathology 99:1346-1354.

Fundecitrus. 2019. Greening aumenta e atinge 19,02\% das laranjeiras de SP e MG. https://www.fundecitrus.com.br/comunicacao/noticias/integra/greeningaumenta-e-atinge-1902-das-laranjeiras-de-sp-e-mg/829

Garbelotto, M., Schmidt, D., Swain, S., Hayden, K., and Lione, G. 2017. The ecology of infection between a transmissive and a dead-end host provides clues for the treatment of a plant disease. Ecosphere 8: e01815.

Hung, T. H., Wu, M. L., and Su, H. J. 2000. Identification of alternative hosts of the fastidious bacterium causing citrus greening disease. J. Phytopathol. 148:321-326.

Husain, M. A., and Nath, D. 1927. The citrus psylla (Diaphorina citri, Kuw.) (Psyllidae: Homoptera). Mem. Dep. Agric. India. 10:1-27.

Inoue, H., Ohnishi, J., Ito, T., Tomimura, K., Miyata, S., Iwanami, T., et al. 2009. Enhanced proliferation and efficient transmission of Candidatus Liberibacter asiaticus by adult Diaphorina citri after acquisition feeding in the nymphal stage. Ann. Appl. Biol. 155:29-36. 
Instituto Colombiano Agropecuario. 2015. Resolución No. 00002390. Instituto Colombiano Agropecuario, Bogotá, Colombia. https://www.ica.gov.co/ normatividad/normas-ica/resoluciones-oficinas-nacionales/resolucionesderogadas/res-2390-de-2015.aspx

Jagoueix, S., Bove, J.-M., and Garnier, M. 1994. The phloem-limited bacterium of greening disease of citrus is a member of the $\alpha$ subdivision of the proteobacteria. Int. J. Syst. Bacteriol. 44:379-386.

Jantasorn, A., Duan, Y., Puttamuk, T., Zhang, S., and Thaveechai, N. 2012. Association of "Candidatus Liberibacter asiaticus", the causal agent of citrus huanglongbing in Murraya paniculata and Diaphorina citri in Thailand. Thai J. Agric. Sci. 45:161-170.

Killiny, N. 2016. Metabolomic comparative analysis of the phloem sap of curry leaf tree (Bergera koenegii), orange jasmine (Murraya paniculata), and Valencia sweet orange (Citrus sinensis) supports their differential responses to Huanglongbing. Plant Signal. Behav. 11:e1249080.

King, C. W. H. 2012. Dispersión de Diaphorina citri (Hemiptera: Psyllidae) en el departamento del Tolima (Colombia). Rev. Tumbaga. 2:51-60.

Koizumi, M., Prommintara, M., and Ohtsu, Y. 1996. Wood apple, Limonia acidissima: A new host for the Huanglongbing vector, Diaphorina citri. Pages 271-275 in: Proceedings of the 13th Conference of the IOCV (International Organizaton of Citrus Virologist).

Kunta, M., Li, W., da Graca, J. V., and Levy, L. 2011. Search for Candidatus Liberibacter spp. in citrus and orange jasmine plants and psyllids in Texas by field surveys and multi-loci PCR assays. Phytopathology 101:S195.

Kunta, M., Li, W., da Graca, J. V., Levy, L., de la Garza, C., Parra, C. C., Gonzalez, M., Chavez, S., Louzada, E. S., Nakhla, M. K., and Setamou, M. 2014. A multi-year search for Candidatus Liberibacter spp. in orange jasmine plants in Texas by field surveys and multi-loci PCR assays. Phytopathology 104:63-64.

$\mathrm{Li}, \mathrm{T}$., and Ke, C. 2002. Detection of the bearing rate of Liberobacter asiaticum in the citrus psylla and its host plant Murraya paniculata by nested PCR. Acta Phytophylac. Sin. 29:31-35.

Li, W., Hartung, J. S., and Levy, L. 2006. Quantitative real-time PCR for detection and identification of Candidatus Liberibacter species associated with citrus huanglongbing. J. Microbiol. Methods 66:104-115.

Li, W., Levy, L., and Hartung, J. S. 2009. Quantitative distribution of 'Candidatus Liberibacter asiaticus' in citrus plants with citrus huanglongbing. Phytopathology 99:139-144.

Liu, Y. H., and Tsai, J. H. 2000. Effects of temperature on biology and life table parameters of the Asian citrus psyllid, Diaphorina citri Kuwayama (Homoptera: Psyllidae). Ann. Appl. Biol. 137:201-206.

Lopes, S. A., Bertolini, E., Frare, G. F., Martins, E. C., Wulff, N. A., Teixeira, D. C., et al. 2009a. Graft transmission efficiencies and multiplication of 'Candidatus Liberibacter americanus' and 'Ca. Liberibacter asiaticus' in citrus plants. Phytopathology 99:301-306.

Lopes, S. A., Frare, G. F., Bertolini, E., Cambra, M., Fernandes, N. G., Ayres, A. J., et al. 2009b. Liberibacters associated with citrus huanglongbing in Brazil: 'Candidatus Liberibacter asiaticus' is heat tolerant, ' $\mathrm{Ca}$. L. americanus' is heat sensitive. Plant Dis. 93:257-262.

Lopes, S. A., Frare, G. F., Camargo, L. E. A., Wulff, N. A., Teixeira, D. C., Bassanezi, R. B., et al. 2010. Liberibacters associated with orange jasmine in Brazil: Incidence in urban areas and relatedness to citrus liberibacters. Plant Pathol. 59:1044-1053.

Lopes, S. A., Luiz, F. Q. B. F., Martins, E. C., Fassini, C. G., Sousa, M. C., Barbosa, J. C., et al. 2013. 'Candidatus Liberibacter asiaticus' titers in citrus and acquisition rates by Diaphorina citri are decreased by higher temperature. Plant Dis. 97:1563-1570.

Lopes, S. A., Luiz, F. Q. B. F., Oliveira, H. T., Cifuentes-Arenas, J. C., and Raiol-Junior, L. L. 2017. Seasonal variation of 'Candidatus Liberibacter asiaticus' titers in new shoots of citrus in distinct environments. Plant Dis. 101:583-590.

Lopes, S. A., Martins, E. C., and Frare, E. C. 2005. Detecção de Candidatus Liberibacter americanus em Murraya paniculata. Summa Phytopathol. 31: 48-49.

Lopes, S. A., Martins, E. C., and Frare, G. F. 2006. Detecção de Candidatus Liberibacter asiaticus em Murraya paniculata. Fitopatol. Bras. 31:303.

Mabberley, D. J. 2016. The typification of Murraya, M. exotica, and M. paniculata (Rutaceae): Its significance for the world citrus industry. Taxon. 65:366-371

Manjunath, K. L., Halbert, S. E., Ramadugu, C., Webb, S., and Lee, R. F. 2008. Detection of 'Candidatus Liberibacter asiaticus' in Diaphorina citri and its importance in the management of citrus Huanglongbing in Florida. Phytopathology 98:387-396.
Miyakawa, T. 1980. Experimentally-induced symptoms and host range of citrus Likubin (greening disease). Ann. Phytopathol. Soc. Jpn. 46:224-230.

Morilla, G., Janssen, D., García-Andrés, S., Moriones, E., Cuadrado, I. M., and Bejarano, E. R. 2005. Pepper (Capsicum annиum) is a dead-end host for Tomato yellow leaf curl virus. Phytopathology 95:1089-1097.

Murray, M. G., and Thompson, W. F. 1980. Rapid isolation of high molecular weight plant DNA. Nucleic Acids Res. 8:4321-4326.

Nava, D. E., Torres, M. L. G., Rodrigues, M. D. L., Bento, J. M. S., and Parra, J. R. P. 2007. Biology of Diaphorina citri (Hem., Psyllidae) on different hosts and at different temperatures. J. Appl. Entomol. 131:709-715.

Patt, J. M., and Sétamou, M. 2010. Responses of the Asian citrus psyllid to volatiles emitted by the flushing shoots of its rutaceous host plants. Environ. Entomol. 39:618-624.

Pelz-Stelinski, K. S., Brlansky, R. H., Ebert, T.A., and Rogers, M. E. 2010. Transmission parameters for Candidatus Liberibacter asiaticus by Asian citrus psyllid (Hemiptera: Psyllidae). J. Econ. Entomol. 103:1531-1541.

Raiol-Junior, L. L., Baia, A. D. B., Luiz, F. Q. B. F., Fassini, C. G., Marques, V. V., and Lopes, S. A. 2017. Improvement in the excised citrus leaf assay to investigate inoculation of 'Candidatus Liberibacter asiaticus' by the Asian citrus psyllid Diaphorina citri. Plant Dis. 101:409-413.

Ramadugu, C., Keremane, M. L., Halbert, S. E., Duan, Y. P., Roose, M. L., Stover, E., et al. 2016. Long-term field evaluation reveals Huanglongbing resistance in Citrus relatives. Plant Dis. 100:1858-1869.

Restrepo, O. C., Torres, R. M., and Salazar, R. C. 1987. Comparación del "Tabog" (Swinglea glutinosa Merr) con el limón "Rugoso" (Citrus jambhiri Swingle) y la mandarina "Cleópatra" (C. reticulata Swingle) como porta-injerto para la lima ácida "Tahiti" (C. aurantifolia Swingle). Acta Agron. 37:43-50.

Rondón, A., Hung, G., Reyes, F., and Solorzano, R. 1993. Reacción de patrones cítricos a Phytophthora nicotianae B. de Haan. var. parasitica (Dastur) Waterh, en condiciones de umbráculo. Agron. Trop. 43: 117-125.

Sétamou, M., Alabi, O. J., Kunta, M., Jifon, J. L., and da Graça, J. V. 2016. Enhanced acquisition rates of 'Candidatus Liberibacter asiaticus' by the Asian citrus psyllid (Hemiptera: Liviidae) in the presence of vegetative flush growth in citrus. J. Econ. Entomol. 109:1973-1978.

Sétamou, M., Alabi, O. J., Simpson, C. R., and Jifon, J. L. 2017. Contrasting amino acid profiles among permissive and non-permissive hosts of Candidatus Liberibacter asiaticus, putative causal agent of Huanglongbing. PLoS One 12:e187921.

Subandiyah, S., Himawan, A., Joko, T., Astuti, I. P., Holford, P., Beattie, G. A. C., et al. 2008. Colonization of Asiatic citrus psyllid and Huanglongbing development on Citrus and Citrus relatives in Indonesia. Page 393 in: Proceedings of the International Research Conference on Huanglongbing. J. H. Graham and T. R. Gottwald, eds. Plant Management Network, Orlando, FL. http://www.plantmanagementnetwork.org/proceedings/irchlb/2008/Proceedings.Conference.on.HLB.2008.V14.pdf

Teixeira, D. C., Saillard, C., Eveillard, S., Danet, J. L., da Costa, P. I., Ayres, A. J., et al. 2005. "Candidatus Liberibacter americanus", associated with citrus huanglongbing (greening disease) in Sao Paulo State, Brazil. Int. J. Syst. Evol. Microbiol. 55:1857-1862.

Thao, M. L., Moran, N., Abbot, P., Brennan, E. B., Burckhardt, D. H., and Baumann, P. 2000. Cospeciation of psyllids and their primary prokaryotic endosymbionts. Appl. Environ. Microbiol. 66:2898-2905.

Tirtawidjaja, S. 1981. Insect, dodder, and seed transmissions of citrus vein phloem degeneration (CVPD). Pages 469-471 in: Proceedings of the Fourth International Society of Citriculture Congress. International Society of Citriculture, Tokyo, Japan.

Tomaseto, A. F., Krugner, R., and Lopes, J. R. S. 2016. Effect of plant barriers and citrus leaf age on dispersal of Diaphorina citri (Hemiptera: Liviidae). J. Appl. Entomol. 140:91-102.

Tomaseto, A. F., Marques, R. N., Fereres, A., Zanardi, O. Z., Volpe, H. X. L., Alquézar, B., et al. 2019. Orange jasmine as a trap crop to control Diaphorina citri. Sci. Rep. 9:2070.

Venning, F. D. 1957. Trials with Swinglea glutinosa (Blanco) Merr. as a rootstock for citrus. Pages 306-307 in: Proceedings of the Florida Horticultural Society, Florida. https://journals.flvc.org/fshs/article/view/101485

Walter, A. J., Hall, D. G., and Duan, Y. P. 2012. Low incidence of 'Candidatus Liberibacter asiaticus' in Murraya paniculata and associated Diaphorina citri. Plant Dis. 96:827-832.

Wu, F., Huang, J., Xu, M., Fox, E. G. P., Beattie, G. A. C., Holford, P., et al. 2018. Host and environmental factors influencing 'Candidatus Liberibacter asiaticus' acquisition in Diaphorina citri. Pest Manag. Sci. 74: 2738-2746.

Yan, H., Zeng, J., and Zhong, G. 2015. The push-pull strategy for citrus psyllid control. Pest Manag. Sci. 71:893-896. 